\title{
Appraisal of groundwater resources in an island condition
}

\author{
N C Mondal ${ }^{1,2, *}$, V S Singh ${ }^{1}$, D V SARWAdE ${ }^{3}$ and M V NANDAKUmaR ${ }^{1}$ \\ ${ }^{1}$ National Geophysical Research Institute (Council of Scientific 83 Industrial Research) \\ Uppal Road, Hyderabad 500 606, India. \\ ${ }^{2}$ Present Address: $321 E$ Scoates Hall, Department of Biological \&3 Agricultural Engineering, \\ Texas A 83 M University, 2117 TAMU, College Station, Texas 77843-2117, USA. \\ ${ }^{3}$ Central Soil \& Materials Research Station, New Delhi 110 016, India. \\ *e-mail: ncmngri@yahoo.co.in
}

A group of 36 coral islands is being scattered in the Arabian Sea off the western coast of India. On such islands, groundwater is the only source of fresh water for the islanders. The demand for groundwater is increasing every year due to growing population and urbanization. On the other side the peculiar hydrologic, geologic and geomorphic features restrict the availability of groundwater. Thus a proper understanding of the groundwater condition is important in order to meet this increasing demand and also to formulate future development and management strategies. Detailed hydrogeological, geophysical and hydrochemical studies had been carried out to identify potential fresh groundwater resources and quantify vulnerable parts of Andrott Island, Union Territory of Lakshadweep. Systematic collection and analysis of hydrological, geophysical and hydrochemical data gives an early signal of deterioration in groundwater quality in the peripheral parts of eastern and western coasts of this island and it suggests immediate measures for arresting the deterioration in groundwater quality as well as augmentation for restoration of aquifer in some parts of the island.

\section{Introduction}

The increasing population has led to the increase in demand for potable water. In recent years to meet the increasing demand, there has been indiscriminate exploitation of groundwater resources both on main land and island. There are several tiny islands off western coast of India (Mallik 2001) where the population density is very high. Groundwater is the only source of fresh water on these islands. There is large pumping of groundwater to meet various needs, which has led to the deterioration in groundwater quality. The new technology such as solar pump has added further pumpage of groundwater beyond the actual needs. As a consequence of indiscriminate exploitation, the quality in some parts of these islands has already started deteriorating (Sarwade et al 2007). Andrott Island, Union Territory of Lakshadweep is also under the same conditions. It is one of the thickly populated islands (Census 2001, 10,720 people) among the group of Lakshadweep Islands. In this island groundwater occurs as thin lens floating on the seawater, in coral limestone. The major problem experienced by the islanders is the less availability of fresh water. The scarcity of fresh water is due to the unsuitable conditions. The demand for groundwater is increasing every year because of rapid population growth and urbanization. In this context, a critical evaluation of the fresh groundwater, in terms of availability, distribution and quality, is needed in order to meet this increasing demand for fresh water and also to formulate future planning and development of water resources. It is therefore, imperative to collect hydrogeological, geophysical and hydrochemical data to assess deterioration in groundwater quality, which helps to augment the restoration of aquifer on this Island.

Keywords. Coral island; groundwater resources; seawater intrusion; Lakshadweep; India. 


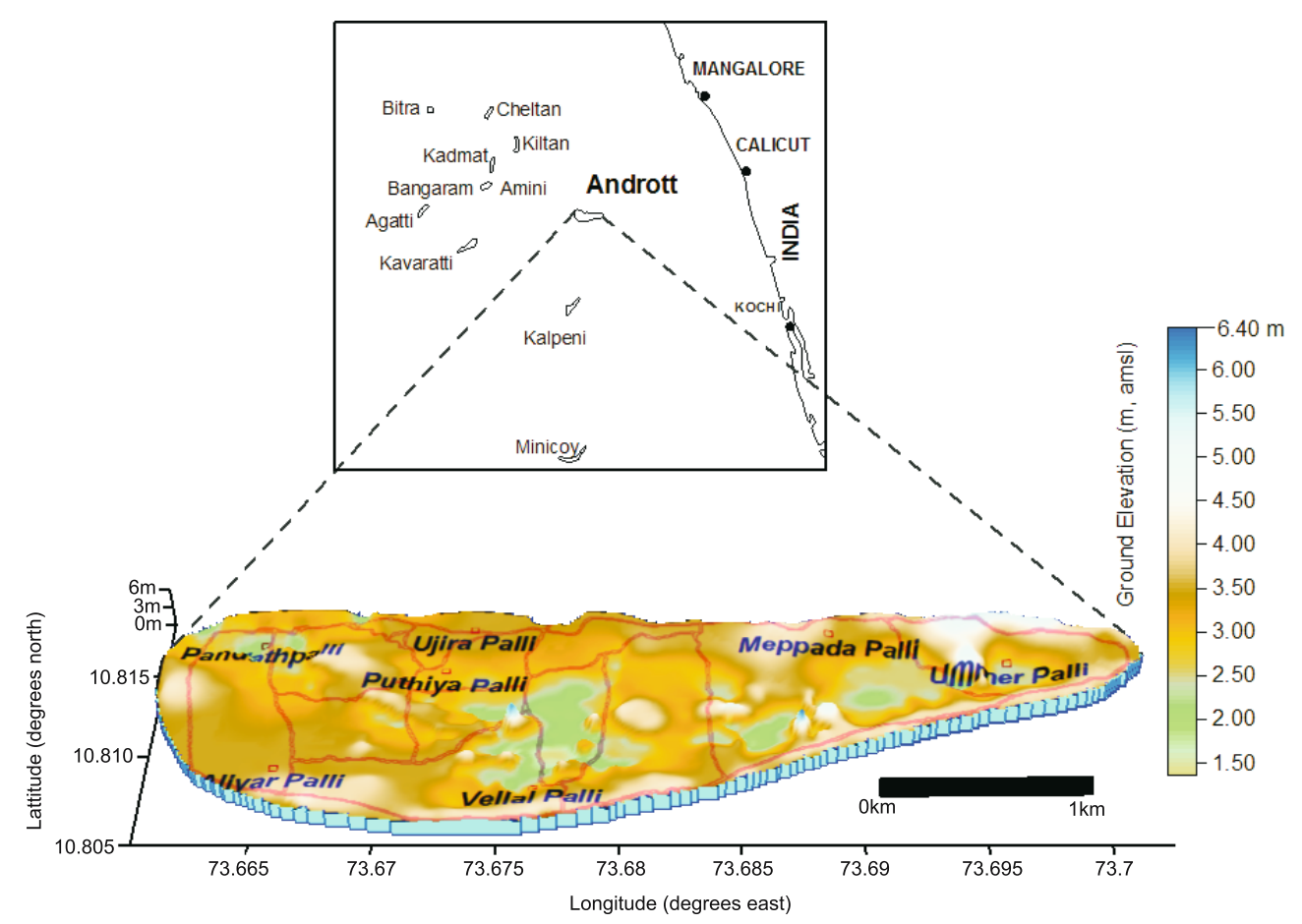

Figure 1. Location map of Andrott Island, India.

\section{Brief of Andrott Island}

Lakshadweep is an archipelago of coral islands in the Arabian Sea off the western coast of India. In the range of $220-400 \mathrm{~km}$ off the western coast of India, there are about 36 islands, 12 atolls, 3 reefs and 5 submerged coral banks spread over an area of $32 \mathrm{~km}^{2}$ in the Arabian Sea (Wagle and Kunte 1993; Nazeeb 1995; Mallik 2001). Only 10 of these islands are inhabited. Among them the easternmost inhabited island is Andrott, where the population density is about 2233 people $/ \mathrm{km}^{2}$. This island lies between latitude: $10^{\circ} 48^{\prime} 08^{\prime \prime}-10^{\circ} 48^{\prime} 58^{\prime \prime} \mathrm{N}$ and longitude: $75^{\circ} 39^{\prime} 35^{\prime \prime}-75^{\circ} 42^{\prime} 09^{\prime \prime} \mathrm{E}$ (figure 1). It is of an elliptical shape with major axis in E-W direction (major axis: $4.25 \mathrm{~km}$ and minor axis: $2.60 \mathrm{~km}$ ) and an areal extent of $4.9 \mathrm{~km}^{2}$ whereas all other islands have $\mathrm{N}-\mathrm{S}$ directions. The topography is undulating and the ground surface is about few meters to 8.0 meters above mean sea level (amsl). The island does not have any lagoon around it and is enveloped with sparkling white carbonate sand beach. The island is covered by medium-to-fine grained assorted coral sand, mixed with coral pebbles at some places, which overlies a thin hard coral limestone at a depth of $1.5-3.0 \mathrm{~m}$. The hard coral limestone is characterized by cavities. This hard coral limestone is seen in the well sections. Loose coral sand underlies the hard coral limestones (Wagle and Kunte 1993; Nazeeb 1995; Mallik 2001; Muralidharan and Pravan Kumar 2001; Revichandran et al 2001). The most important sediment forming site is the reef area. Geomorphologically, the island has storm beach, beach ridges, sand dunes (eolian/anhropogenic) and hinterland. The island is generally flat with localized depressions or sand mounds, which are largely due to man-made activities. The rainfall recorded at the rain gauge station (shown in figure 2) was collected and the monthly average rainfall of 5 years (20002005 ) is presented in figure 3 . The average annual rainfall is $1817 \mathrm{~mm}$. About $72 \%$ of the annual rainfall is received during the southwest monsoon in the months of June to September, 18\% during northeast monsoon during October-December and the remaining $10 \%$ is received as pre-monsoon showers. Due to high permeable coral sand on the surface, most of the rain percolate down and finally goes as subsurface runoff to sea. There are no signatures of drainage on the topography. Major vegetation on the island is coconut with about more than 100,000 trees (Prasada Rao 1994). Most of the islanders use groundwater for their various needs. There is no surface water storage on the island and there has been growing demand for potable water in the recent years, which has lead to increase in the exploitation of groundwater.

\section{Materials and methods}

Measurements of groundwater levels were done using water level indicator (IGIS, Hyderabad) at 35 observation wells during pre- and post-monsoons. 


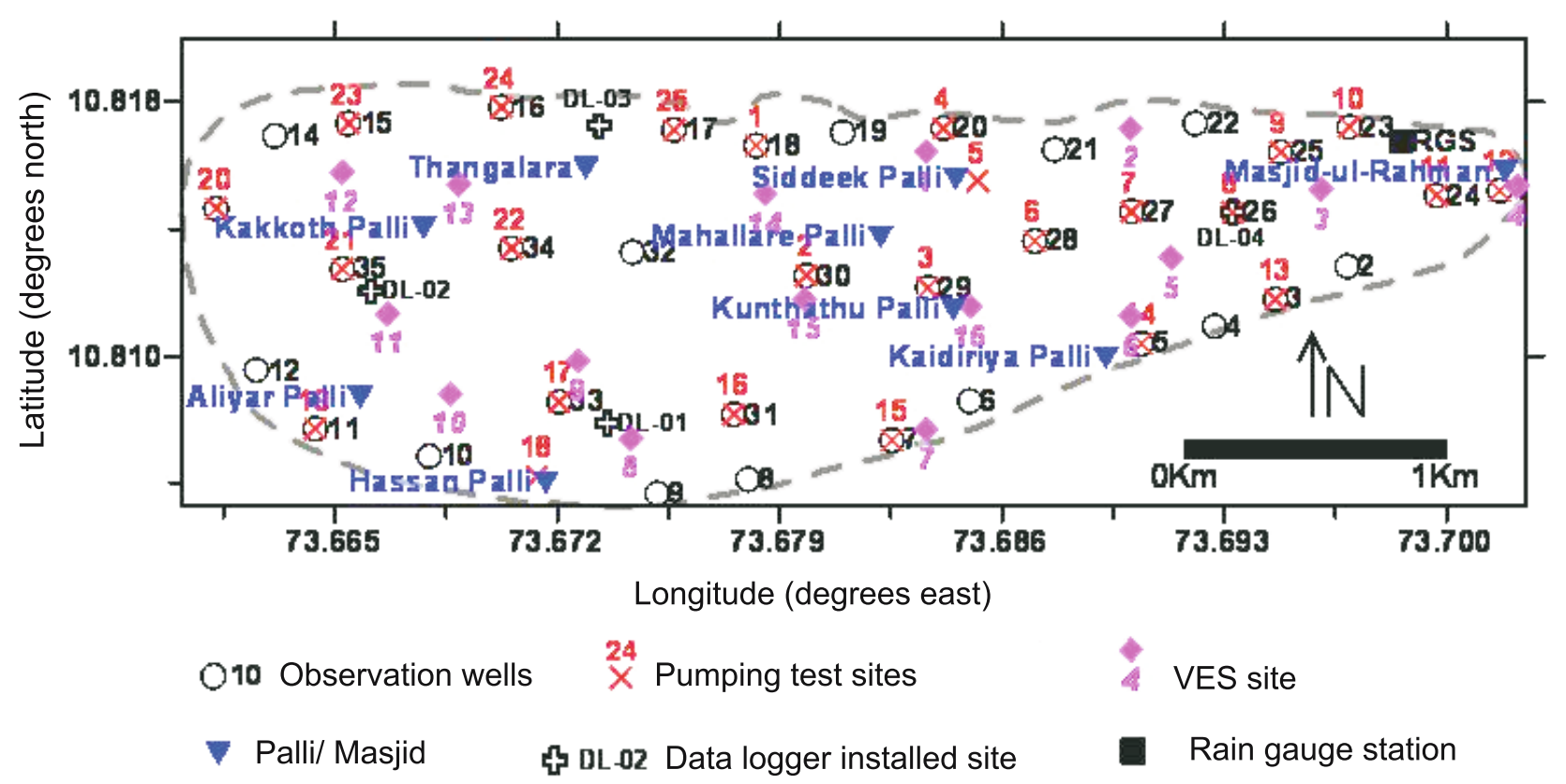

Figure 2. Location of observation wells.

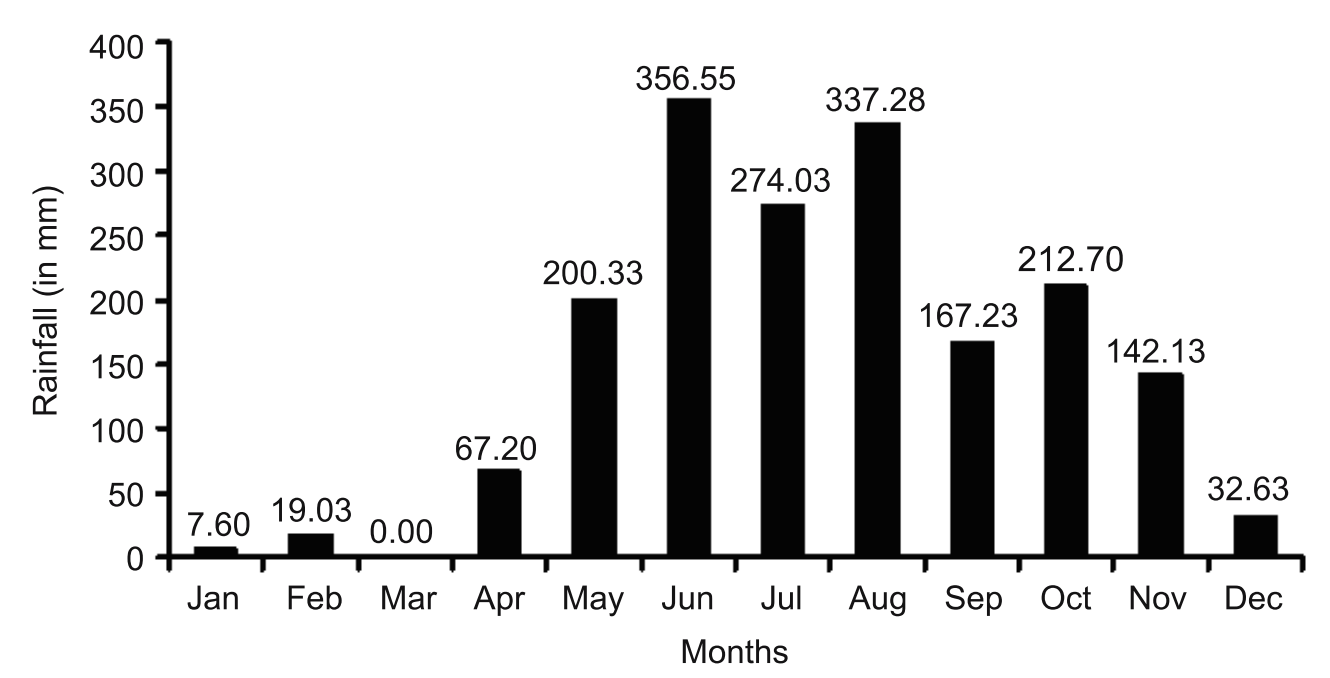

Figure 3. Monthly average rainfall of 5 years (2000-2005).

The water level fluctuations were also observed at four open wells using water level data logger (Global Water Instrumentation, Inc, USA). Discharge rate of the pump, duration of pumpage and quantity of water pumped and whether pumping once or twice a day are collected for calculation of the groundwater draft in the entire island. To estimate the aquifer properties, pumping test was carried out at 25 locations on the island and the data was analyzed by numerical method (Singh 1999). A total of 16 Vertical Electrical Soundings (VES) were conducted using Schlumberger electrode configuration for a spreading of $40-60 \mathrm{~m}$. Initially VES data have been interpreted through curve matching technique (Orellana and Mooney 1966) and then interpreted by computer program, which involves the inverse modeling method (Vender Velpen 1988). Total 35 groundwater samples were collected from open wells in each season during pre- and post-monsoons, simultaneously the electrical conductivity (EC) and $\mathrm{pH}$ were measured in situ using portable kits. The water samples were collected in 1-L polythene bottles for major ion analyses. The groundwater from each dug wells was sampled at $0.5 \mathrm{~m}$ below the water table. The water samples were used for the analysis of major cations $\left(\mathrm{Na}^{+}, \mathrm{K}^{+}, \mathrm{Ca}^{2+}, \mathrm{Mg}^{2+}\right)$ and major anions $\left(\mathrm{Cl}^{-}, \mathrm{HCO}_{3}^{-}, \mathrm{NO}_{3}^{-}\right.$and $\left.\mathrm{SO}_{4}^{2-}\right)$. The chemical analysis was carried out at the laboratory of National Geophysical Research Institute (NGRI), 
Hyderabad using standard procedures (Trivedy and Goel 1984; APHA 1985). The analytical precision for the measurements of cations and anions, indicated by the ionic balance error (IBE) was computed on the basis of ions expressed in me/l. The value of IBE was observed to be within a limit of $\pm 5 \%$ (Mandel and Shiftan 1980; Domenico and Schwartz 1990).

\section{Results and discussion}

\subsection{Hydrogeological investigation}

\subsubsection{Water level}

Groundwater occurs under phreatic condition in the coral sand underlined by shale-limestone, in the form of floating lens. The groundwater is being exploited for various needs of islanders through shallow dug wells. There are about $2143 \mathrm{dug}$ wells with density of $437 \mathrm{dug}$ wells $/ \mathrm{km}^{2}$. Of these 865 wells are not in use because of the saline nature of water. The recent development has brought many of these wells equipped with solar pumps, which in turn has increased the exploitation of groundwater. The depth of the wells varies from less than a meter to about $5.0 \mathrm{~m}$ below ground level (bgl). The diameter of the wells varies from less than a meter to about $2.0 \mathrm{~m}$. Groundwater is mainly used for domestic purposes, as hardly there is any industry or agriculture.

The water levels were monitored at 35 observation wells (as shown in figure 2) during preand post-monsoon. The water level contours and its fluctuation in both the seasons were drawn with the help of Surfer v.7.0 software using krigging method. These are shown in figure 4 . This shows that the water level varies from 1.374 to $3.520 \mathrm{~m}$ and 1.234 to $3.350 \mathrm{~m}$ during pre- and postmonsoon seasons respectively. The water level fluctuation for both the seasons varies from zero to $0.542 \mathrm{~m}(\mathrm{bgl})$ with average $0.224 \mathrm{~m}(\mathrm{bgl})$ as shown in figure $4(\mathrm{C})$. This fluctuation in the peripherals varies from zero to $0.440 \mathrm{~m}(\mathrm{bgl})$ with a mean value of $0.179 \mathrm{~m}(\mathrm{bgl})$ whereas in the central part from 0.170 to $0.542 \mathrm{~m}$ (bgl) with a mean value of $0.309 \mathrm{~m}$ (bgl). Thickness of the fresh groundwater lens was also calculated by deducting the water levels from the mean sea level (msl), which is presented in figure 5 . This shows that the thickness of groundwater lens is thicker in the centre $(\approx 0.56 \mathrm{~m})$ and thinner at the peripherals $(\approx-0.04 \mathrm{~m})$. It indirectly implies that the random withdrawal of the groundwater along the peripheries of this island may cause seawater ingress converting the freshwater well into a brackish one. The seawater may be in hydraulic continuity with the groundwater regimes and the same is evidenced by the tidal influence in almost all the dug wells of the island (Banerjee et al 2008), which are reflected on the well hydrographs.

\subsubsection{Groundwater draft}

In the island, each house is having its own well for day-to-day needs. Some of the wells are equipped by the pumps and the rest, rope and pulley method is used. For calculation of draft on the island data, viz., discharge rate of the pump, duration of pumpage and quantity of water pumped and whether pumping once or twice a day are collected. The zonewise draft of groundwater has been shown in figure 6 . It shows the total draft on the island as $0.0300 \mathrm{MCM} /$ year highest being at the Edichery (0.0173 MCM/year) and lowest at the Pandath (0.0027 MCM/year).

\subsubsection{Aquifer properties}

Estimation of aquifer parameters is of much importance to know the groundwater potential zones (Singh 1999). Aquifer parameters namely, transmissivity $(T)$ and storativity $(S)$ are calculated by conducting short duration pumping tests at 25 locations on the island (figure 2). The depth and thickness of the fresh water aquifer on the island are calculated. It varies from $-0.04 \mathrm{~m}$ to $0.56 \mathrm{~m}$. Considering that the well is being pumped at a constant rate of $Q$, Darcy's law can be written as:

$$
Q=-2 \Pi r K m\left(\frac{\partial s}{\partial r}\right)
$$

where $K$ is the permeability of aquifer, $m$ is saturated thickness of fresh water, $s$ is drawdown, $r$ is radial distance from well, and $T(=K * m)$ is transmissivity.

As the hydraulic head in the aquifer decreases the water is released at the water table, from the aquifer storage, and at the interface due to Ghyben-Herzberg (GH) effect. In case the lowering of the water table is small during a short duration test, the rate of change of flow with radial distance (neglecting water released at the water table) can be written as:

$$
\frac{\partial Q}{\partial r}=-2 \Pi r(1+\alpha) S\left(\frac{\partial s}{\partial t}\right),
$$

where $S$ is storage coefficient of the aquifer, and $\alpha$ is Ghyben-Herzberg ratio. 


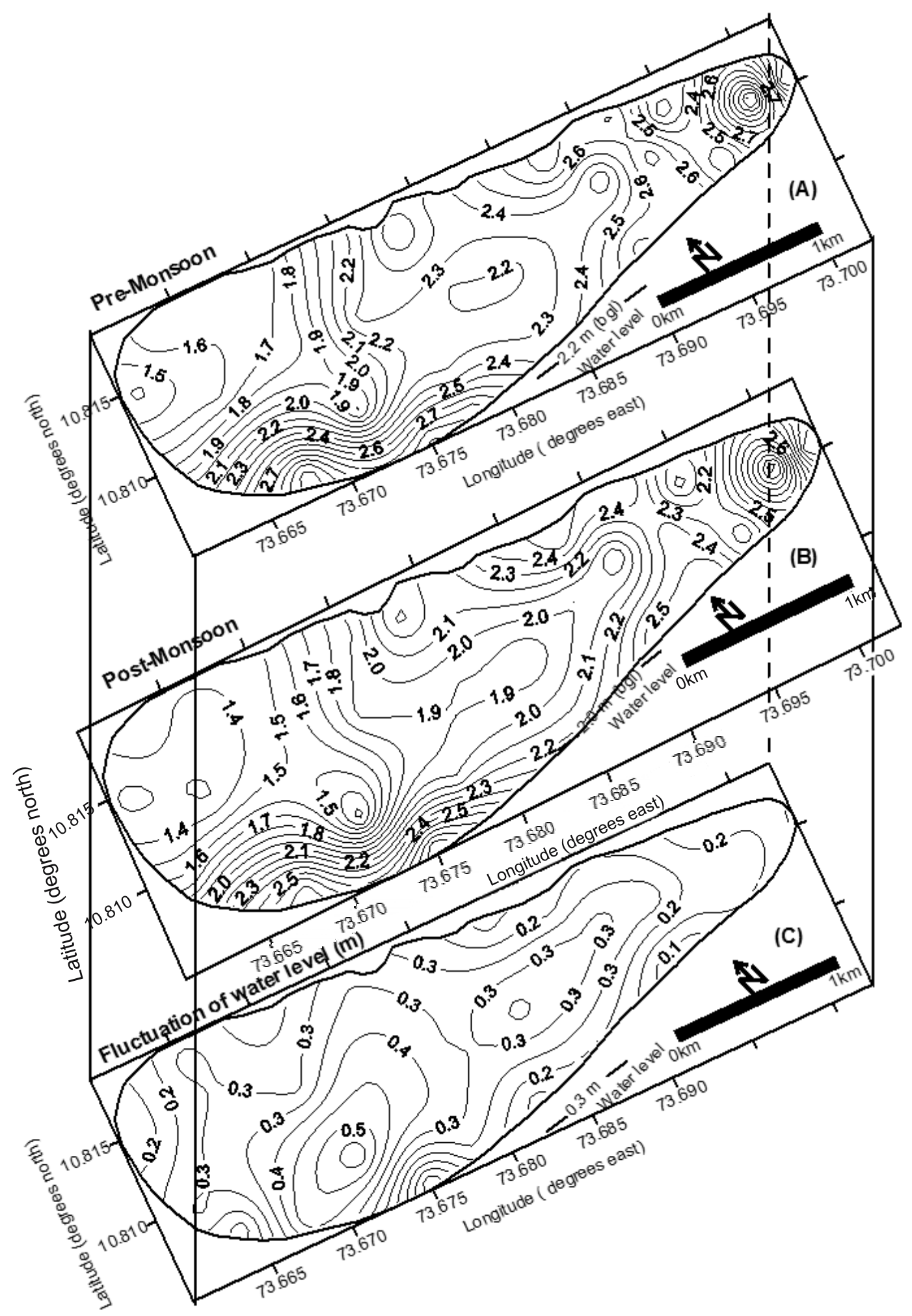

Figure 4. (A) Water level contours ( $\mathrm{m}, \mathrm{bgl}$ ) in pre-monsoon, (B) water level contours (m, bgl) in post-monsoon and (C) water level fluctuation (m) during pre- and post-monsoons, Andrott Island, India.

Combining equations (1) and (2) one gets:

$T\left(\frac{\partial^{2} s}{\partial r^{2}}+\left(\frac{1}{r}\right)\left(\frac{\partial s}{\partial r}\right)\right)=(1+\alpha) S\left(\frac{\partial s}{\partial t}\right)$.
Equation (3) is the governing flow equation of the radial flow towards a pumping well in an island taking into account the GH effect. The radial flow (equation 3) is similar to the conventional 


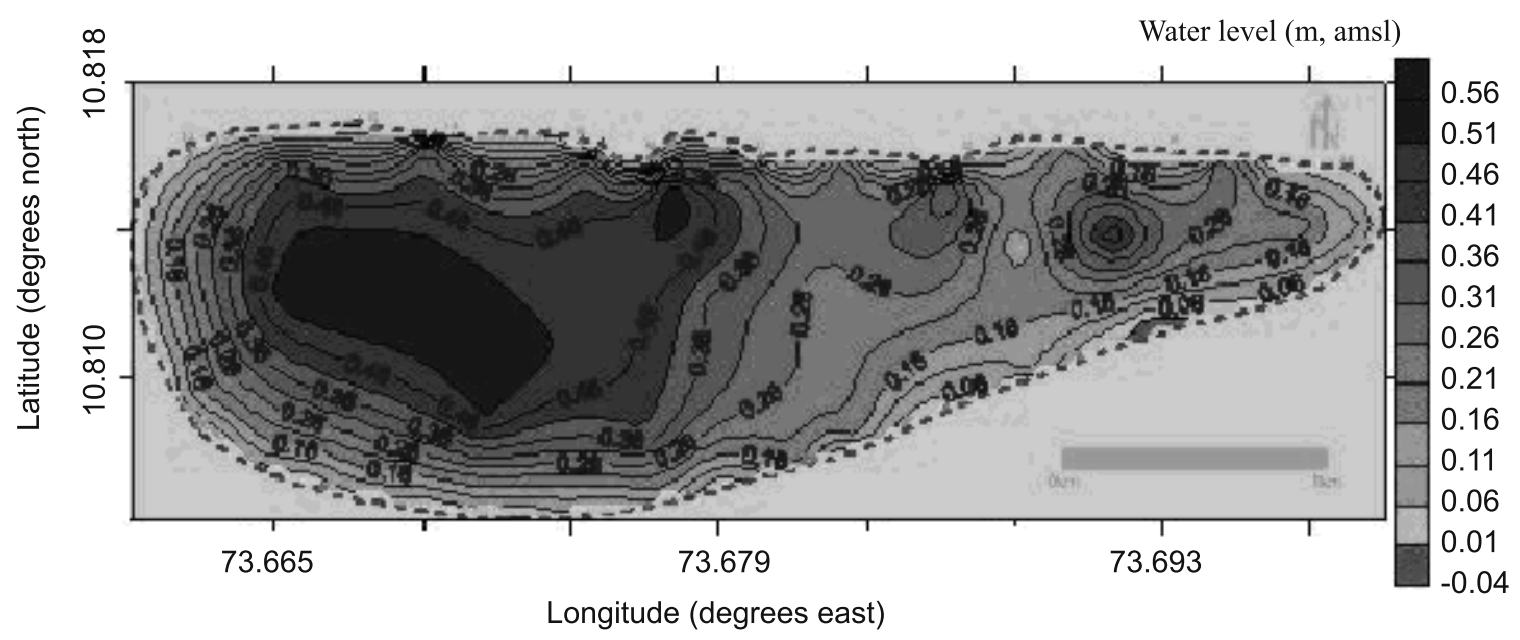

Figure 5. Thickness of fresh groundwater lens (m, amsl).

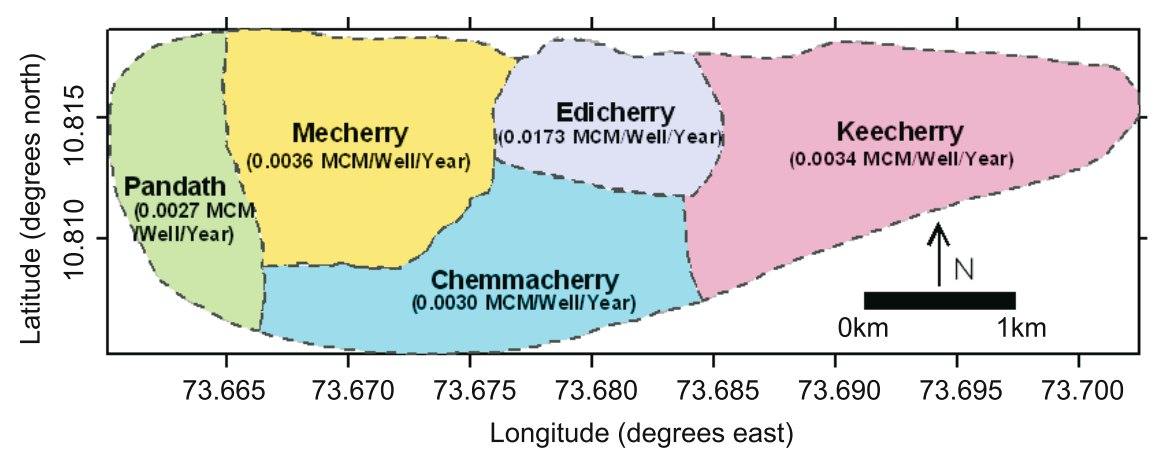

Figure 6. Groundwater draft on Andrott Island.

radial flow equation except the term associated with $S$. The finite difference method (Rushton and Redshaw 1979) is adopted with necessary modification to the term associated with $S$.

Since most of the wells are partially penetrating, the two layers finite difference model is used to effectively represent the partial penetration of wells (Gupta and Singh 1988). The upper layer is fully penetrated by the well, and pumping is restricted to this layer. Since the change in the water table affects the interface which lies in the lower layer, the term associated with $S$ of the lower layer is modified as indicated in equation (3). The boundary conditions such as well storage and leakage through the well bottom have also been taken into account (Rushton and Redshaw 1979; Gupta and Singh 1988).

The drawdown observed during the pumping phase varied from 0.026 to $0.382 \mathrm{~m}$ and 66.67 to $98.09 \%$ recovery was taken depending upon the field situations. Initial guess values of the aquifer parameters are considered based on the recovery rate into the wells. The calculated drawdown and recovery are matched with the observed data. The aquifer parameters are then progressively varied to get a close match with the observed drawdown and recovery. The well hydrographs depicting calculated and observed drawdown and recovery are shown in figure 7 . The estimated aquifer parameters are shown in table 1 . The $T$-values varies from 20 to $1015 \mathrm{~m}^{2} /$ day and the storativity $(S)$ value ranges from $5.0 \times 10^{-6}$ to $9.5 \times 10^{-2}$. This table shows that $T<250 \mathrm{~m}^{2} /$ day in $68 \%$ of wells, whereas $T: 250-500 \mathrm{~m}^{2}$ day in $24 \%, 500-750 \mathrm{~m}^{2} /$ day in $4 \%$, it is $>1000 \mathrm{~m}^{2} /$ day in $4 \%$ of wells. The contour map of $T$ values (figure 8 ) shows that it is comparatively higher in the eastern and central parts of the island. The aquifer characteristics combined with the groundwater draft give a clue that there is more possibility of seawater ingress at the eastern part of the island, which will be more vulnerable.

\subsection{Geophysical investigation}

Among the geophysical methods, resistivity method (Vertical Electrical Sounding) was used to know the thickness of different geoelectrical layers. 

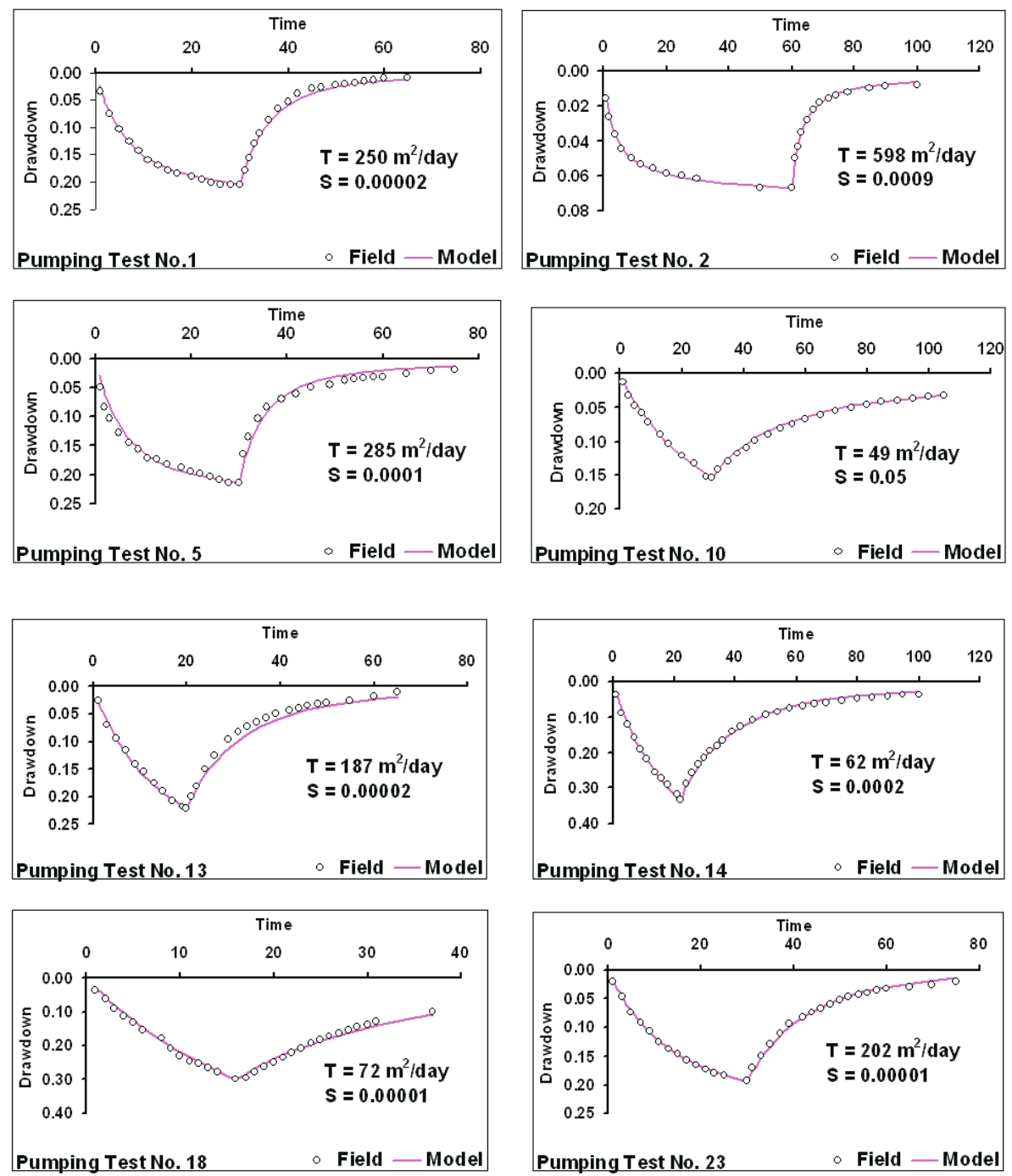

Figure 7. Typical curves of field and model, Andrott Island.

At 16 locations (shown in figure 2), vertical electrical sounding (VES) studies with Schlumberger array were carried out for a spreading of 40-60 m. The field data was plotted on log-log sheet (figure 9). All the field curves represent 3-4 layers geoelectric sections. 'Q' type curves $\left(\rho_{1}>\rho_{2}>\rho_{3}\right)$ are seen in the VES sites which are nearer to coast and 'HQ' type curves $\left(\rho_{1}>\rho_{2}<\rho_{3}>\rho_{4}\right)$ in the centre of the island. The apparent resistivity values show a decreasing trend with depth. The VES data have been interpreted through curve matching techniques; using Orellana and Mooney (1966) and then interpreted by RESIST-88 program (Vender Velpen 1988), which involves the inverse modeling method. Typical outputs of interpreted VES data are shown in figure 10. The details of sub-surface lithology, as observed from the nearby existing dug wells and the water quality of the surrounding wells have also considered during the interpretation of the VES data. The results show three to four layers situation (table 2). The table shows top coral sandy soil having a resistivity range of

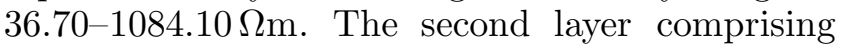
of fresh groundwater shows a resistivity range of $20.0-69.0 \Omega \mathrm{m}$. The third and fourth layers at few places comprise of brackish water shown minimum resistivity of $2.6 \Omega \mathrm{m}$. The ranges of resistivity values of the subsurface strata are as follows:

36-1084 $\Omega \mathrm{m} \quad$ Top sandy soil with corals 20-69 $\Omega \mathrm{m} \quad$ Hard coral limestone with cavities 15-123 $\Omega \mathrm{m} \quad$ Loose coral sand $<15 \Omega \mathrm{m} \quad$ Loose sand with brackish water

Using the true resistivities at different depths $(1.0,2.5,5.0,10.0,20.0$, and $30.0 \mathrm{~m})$ contours are drawn. The true resistivity varies from 36.70 to $1084.10 \Omega \mathrm{m}$ at $1.0 \mathrm{~m}$ depth and from 20.0 to $802.0 \Omega \mathrm{m}, 24.50$ to $94.60 \Omega \mathrm{m}, 4.10$ to $122.60 \Omega \mathrm{m}$, 2.60 to $65.10 \Omega \mathrm{m}, 2.60$ to $37.90 \Omega \mathrm{m}$ at depths 2.5 , $5.0,10.0,20.0,30.0 \mathrm{~m}$ respectively. The contours 
Table 1. Pumping test details, Andrott Island.

\begin{tabular}{|c|c|c|c|c|c|c|c|}
\hline \multirow{2}{*}{$\begin{array}{l}\text { Pumping } \\
\text { test no. }\end{array}$} & \multirow{2}{*}{$\begin{array}{c}\text { Depth } \\
(\mathrm{m}, \mathrm{bgl})\end{array}$} & \multirow{2}{*}{$\begin{array}{l}\text { Radius } \\
\text { (m) }\end{array}$} & \multirow{2}{*}{$\begin{array}{c}\text { Water level } \\
(\mathrm{m}, \mathrm{bgl})\end{array}$} & \multicolumn{2}{|c|}{ Observed } & \multicolumn{2}{|c|}{ Results } \\
\hline & & & & $\mathrm{DD}(\mathrm{m})$ & $\operatorname{REC}(\mathrm{m})$ & $T\left(\mathrm{~m}^{2} /\right.$ day $)$ & $S$ \\
\hline 1 & 2.47 & 0.55 & 1.778 & 0.206 & 0.010 & 250.00 & 0.00002 \\
\hline 2 & 2.80 & 0.69 & 1.952 & 0.067 & 0.008 & 598.00 & 0.0009 \\
\hline 3 & 2.40 & 0.60 & 1.420 & 0.210 & 0.004 & 250.00 & 0.00002 \\
\hline 4 & 3.10 & 0.69 & 2.234 & 0.376 & 0.032 & 165.00 & 0.008 \\
\hline 5 & 2.40 & 0.59 & 1.926 & 0.214 & 0.020 & 285.00 & 0.0001 \\
\hline 6 & 2.40 & 0.53 & 1.630 & 0.085 & 0.010 & 210.00 & 0.008 \\
\hline 7 & 3.00 & 0.54 & 2.082 & 0.204 & 0.009 & 185.00 & 0.00007 \\
\hline 8 & 2.07 & 0.54 & 1.540 & 0.104 & 0.007 & 340.25 & 0.000017 \\
\hline 9 & 2.70 & 0.59 & 1.970 & 0.128 & 0.010 & 297.00 & 0.001 \\
\hline 10 & 2.90 & 0.82 & 2.190 & 0.154 & 0.032 & 49.00 & 0.05 \\
\hline 11 & 4.04 & 0.60 & 3.474 & 0.026 & 0.006 & 1015.00 & 0.095 \\
\hline 12 & 2.17 & 0.98 & 1.602 & 0.238 & 0.030 & 134.50 & 0.00003 \\
\hline 13 & 3.23 & 0.67 & 2.566 & 0.222 & 0.012 & 187.00 & 0.00002 \\
\hline 14 & 3.03 & 0.52 & 2.030 & 0.334 & 0.036 & 62.00 & 0.0002 \\
\hline 15 & 3.42 & 0.77 & 2.290 & 0.152 & 0.050 & 50.85 & 0.05 \\
\hline 16 & 3.00 & 0.74 & 2.300 & 0.282 & 0.020 & 42.00 & 0.0001 \\
\hline 17 & 3.49 & 0.58 & 2.772 & 0.212 & 0.011 & 188.00 & 0.0008 \\
\hline 18 & 3.35 & 0.51 & 2.290 & 0.300 & 0.100 & 72.00 & 0.00001 \\
\hline 19 & 2.97 & 0.68 & 2.320 & 0.320 & 0.048 & 30.25 & 0.0001 \\
\hline 20 & 2.67 & 0.58 & 1.840 & 0.130 & 0.010 & 218.00 & 0.05 \\
\hline 21 & 2.32 & 0.63 & 1.590 & 0.310 & 0.058 & 20.00 & 0.0009 \\
\hline 22 & 2.48 & 0.60 & 1.690 & 0.127 & 0.005 & 323.00 & 0.00004 \\
\hline 23 & 2.30 & 0.69 & 1.624 & 0.194 & 0.022 & 202.00 & 0.00001 \\
\hline 24 & 2.43 & 0.62 & 1.524 & 0.382 & 0.036 & 96.00 & 0.000005 \\
\hline 25 & 2.38 & 0.74 & 1.832 & 0.203 & 0.020 & 157.25 & 0.00005 \\
\hline
\end{tabular}

$\mathrm{DD}=$ Drawdown, REC $=$ Recovery, $T=$ Transmissivity, $S=$ Storativity.

show that at $5.0 \mathrm{~m}$ depth the true resistivity varied between 50 and $100 \Omega \mathrm{m}$, whereas at $10.0 \mathrm{~m}$ depth resistivity decreased upto $5.0-15.0 \Omega \mathrm{m}$ in the eastern part of the island. It also indicates that fresh groundwater is available in the central part of island where the draft is calculated as Edicherry: $0.0173 \mathrm{MCM} /$ year; Mecherry: 0.0036 MCM/year and Chemmacherry: $0.0030 \mathrm{MCM} /$ year. Further at $20.0 \mathrm{~m}$ depth, almost $50 \%$ of the island has shown resistivity varying between 15.0 and $5.0 \Omega \mathrm{m}$. At $30.0 \mathrm{~m}$ depth whole island has shown maximum resistivity of only $15 \Omega \mathrm{m}$ and less than $5 \Omega \mathrm{m}$ in the peripheral parts of eastern and western coasts of the island. The earlier studies have shown this range of resistivity for brackish nature of water (Lloyd et al 1981; Ajaykumar et al 1995; Ajaykumar and Ramachandran 1996) giving another clue for the seawater intrusion.

\subsection{Chemistry of groundwater}

Thirty five groundwater samples were collected for hydrochemical studies. Sampling locations are shown in figure 2. The electrical conductivity (EC) and $\mathrm{pH}$ were measured in situ using portable kits. The samples are analyzed using standard procedures given by Trivedy and Goel (1984) and APHA (1985). Total dissolved solids (TDS) were computed as per Hem (1970) and Karanth (1987). Total Hardness (TH) as $\mathrm{CaCO}_{3}$, Calcium $\left(\mathrm{Ca}^{+}\right)$, Bicarbonate $\left(\mathrm{HCO}_{3}^{-}\right)$and Chloride $\left(\mathrm{Cl}^{-}\right)$were analyzed by volumetric methods. Magnesium $\left(\mathrm{Mg}^{2+}\right)$ was calculated from $\mathrm{TH}$ and Ca contents. Sulphate $\left(\mathrm{SO}_{4}^{2-}\right)$ was estimated by colorimetric technique. All concentrations are expressed in milligrams per litre $(\mathrm{mg} / \mathrm{l})$ except $\mathrm{pH}$. The minimum, maximum and average values of the parameters analyzed are shown in table 3. EC and $\mathrm{Cl}$ are found more than the permissible limits (ISI 1983). EC varies from 598 to $3550 \mu \mathrm{S} / \mathrm{cm}$ and 457 to $1515 \mu \mathrm{S} / \mathrm{cm}$ in preand post-monsoon respectively. Chloride content varies from 28 to $865 \mathrm{mg} / \mathrm{l}$ and from 39 to $348 \mathrm{mg} / \mathrm{l}$ in pre- and post-monsoon respectively. The areal distribution of $\mathrm{EC}$ and $\mathrm{Cl}$ shows higher contents particularly in the peripheral parts of eastern and western coasts of this island. The EC values become diluted during the post-monsoon season, but the higher content of $\mathrm{Cl}$ persists as shown in 


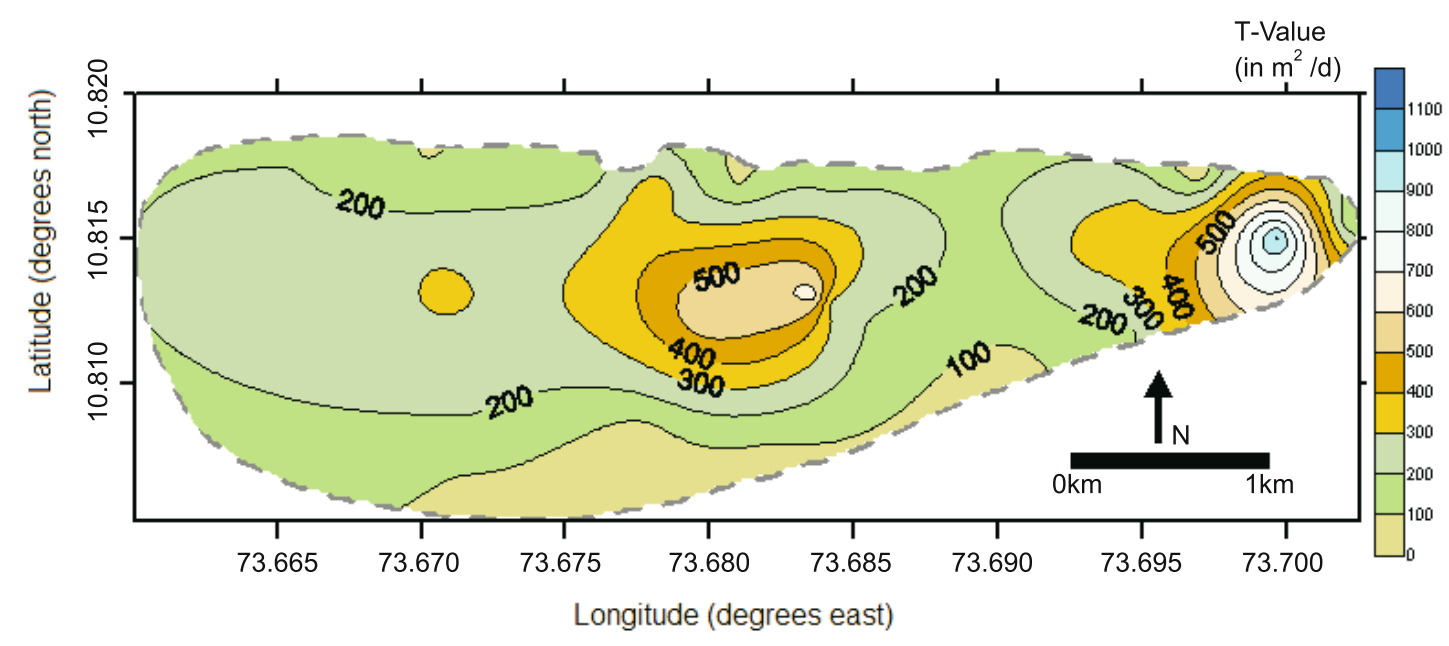

Figure 8. Transmissivity contours, Andrott Island.
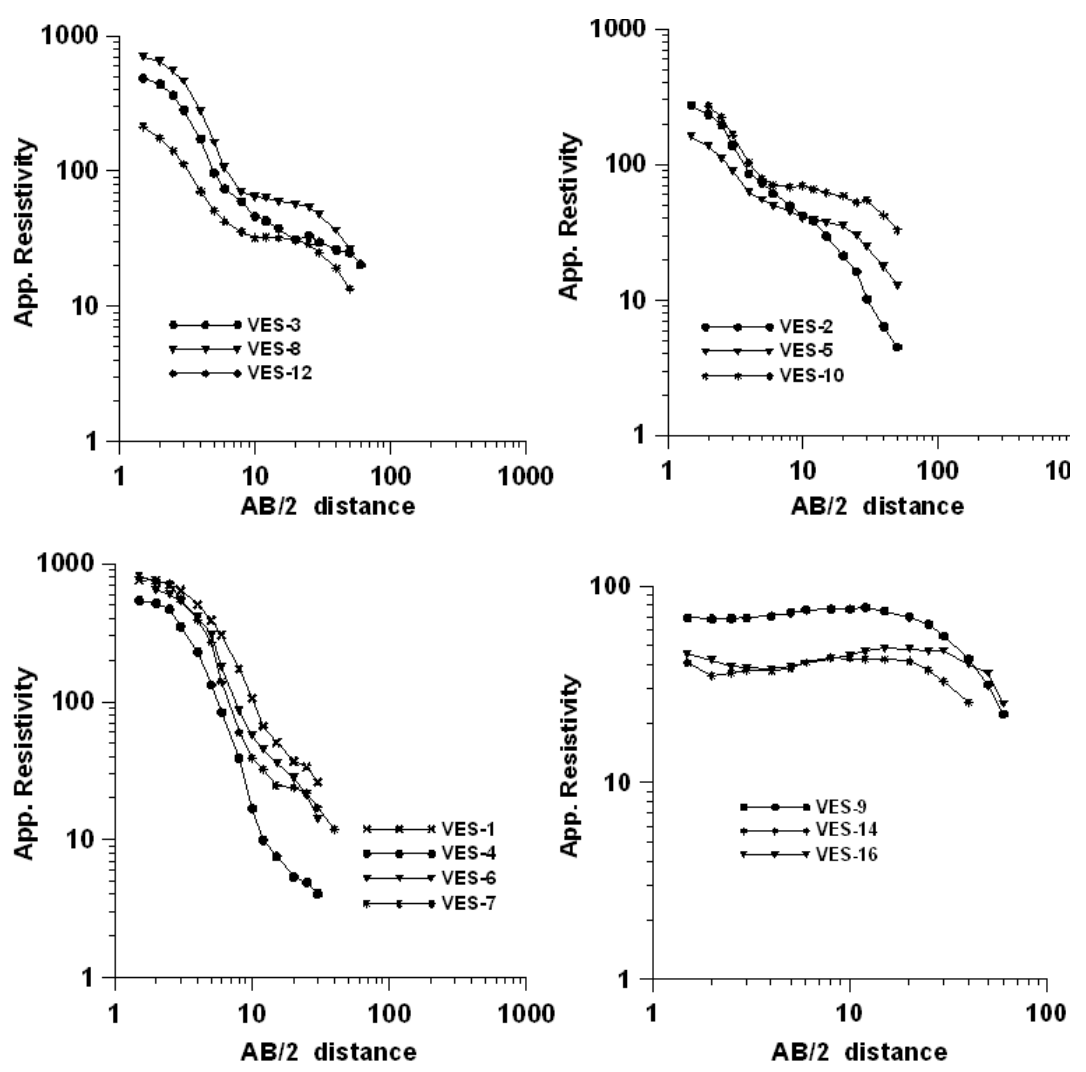

Figure 9. Typical field resistivity curves, Andrott Island.

figures 11 and 12. This illustrates the influence of seawater ingress in the above-mentioned parts.

Comparison of some selected parameters (i.e., $\mathrm{EC}, \mathrm{Ca}, \mathrm{HCO}_{3}$, and $\mathrm{Cl}$ ) of pre- and post-monsoon shows that EC and content of $\mathrm{Cl}$ are higher in pre-monsoon samples, whereas the content of $\mathrm{Ca}$ and $\mathrm{HCO}_{3}$ are higher in post-monsoon samples (Sarwade et al 2007). The higher content of $\mathrm{Cl}$ is an indication of the mixing of slight seawater during non-monsoon period, whereas the higher content of Ca may be due to dissolution of Ca from soil (coral) during infiltration process that takes place during the monsoon season.

In order to understand the role of various cation and anion in the groundwater chemistry during pre- and post-monsoon period, the data were plotted in the tri-linear diagram (Piper 1944). Majority of pre-monsoon samples have shown dominance of $\mathrm{Na}$ and $\mathrm{HCO}_{3}$ whereas during the post-monsoon $\mathrm{Ca}$ and $\mathrm{HCO}_{3}$ dominance is seen amongst cations 

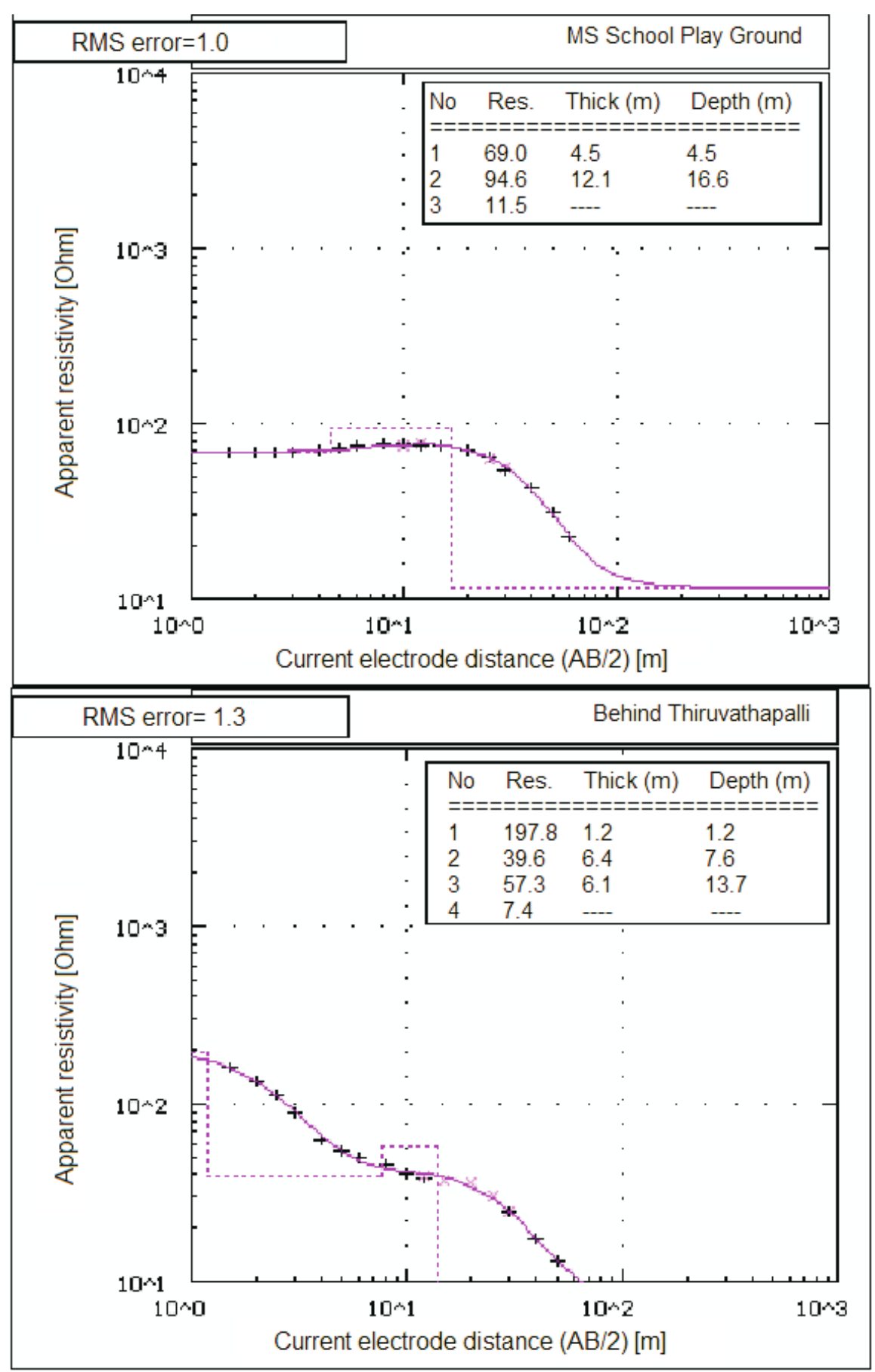

Figure 10. Typical outputs of Resist Program.

and anions, respectively. This dominance of $\mathrm{Na}$ may be due to seawater mixing during premonsoon period. The dominance of bicarbonate as observed during both pre- and post-monsoon may be only due to interaction with coral formation. In the central diamond shaped field, majority of the pre-monsoon samples fall in "no cation or anions exceeds $50 \%$ ' area, whereas all the post-monsoon samples fall in 'carbonate hardness exceeds 50\%' area, indicating that the chemical properties are dominated by alkaline earth $(\mathrm{Ca}, \mathrm{Mg})$ or corals and weak acids $\left(\mathrm{HCO}_{3}\right)$. In the present investigation, the pre- and post-monsoon hydrochemical data are subjected for Principle Component Analysis (PCA) using standard statistical packages on computer. The variables considered are TDS, TH, $\mathrm{Ca}, \mathrm{Mg}, \mathrm{Na}, \mathrm{K}, \mathrm{HCO}_{3}, \mathrm{Cl}, \mathrm{SO}_{4}$, and $\mathrm{NO}_{3}$ (Sarwade et al 2007). The results show that most of the samples are separated out from the cluster and are located nearer to the coast. 
Table 2. Geoelectrical layers obtained from VES studies, Andrott Island.

\begin{tabular}{|c|c|c|c|c|c|c|c|c|c|c|c|}
\hline \multirow[b]{2}{*}{ Sl. no. } & \multirow[b]{2}{*}{ Location of VES site } & \multicolumn{2}{|c|}{ Well details } & \multicolumn{4}{|c|}{ Resistivity $(\Omega \mathrm{m})$} & \multicolumn{4}{|c|}{ Thickness (m) } \\
\hline & & Depth & WL & $\rho_{1}$ & $\rho_{2}$ & $\rho_{3}$ & $\rho_{4}$ & $\mathrm{~h}_{1}$ & $\mathrm{~h}_{2}$ & $\mathrm{~h}_{3}$ & $\mathrm{H}$ \\
\hline 1 & Govt. dispensary & 3.25 & 2.62 & 802.0 & 59.7 & 23.2 & - & 2.5 & 6.1 & - & 8.6 \\
\hline 2 & Keecheri & 3.50 & 2.84 & 354.9 & 48.6 & 4.2 & - & 1.2 & 8.8 & - & 10.0 \\
\hline 3 & Ummer Palli & 2.82 & 2.24 & 623.9 & 54.4 & 32.5 & 11.3 & 1.4 & 3.8 & 23.7 & 28.9 \\
\hline 4 & Near East Light House & 2.65 & 2.19 & 627.0 & 24.5 & 4.1 & - & 1.7 & 3.7 & - & 5.4 \\
\hline 5 & Hussain Palli & 3.02 & 2.26 & 197.8 & 39.6 & 57.3 & 7.4 & 1.2 & 6.4 & 6.1 & 13.7 \\
\hline 6 & Nalgam Palli & 3.27 & 2.72 & 784.4 & 41.8 & 2.6 & - & 2.1 & 11.8 & - & 13.9 \\
\hline 7 & Refai Masjid & 2.72 & 2.37 & 925.8 & 20.0 & 34.4 & 5.8 & 1.9 & 2.6 & 9.4 & 13.9 \\
\hline 8 & Seethi Palli & 1.99 & 1.27 & 864.4 & 47.3 & 117.9 & 12.5 & 1.6 & 5.6 & 6.8 & 14.0 \\
\hline 9 & MG High School & 2.97 & 2.30 & 69.0 & 94.6 & 11.5 & - & 4.5 & 12.1 & - & 16.6 \\
\hline 10 & Mohidden Palli & 3.50 & 2.92 & 546.7 & 65.1 & 14.0 & - & 1.0 & 21.2 & - & 22.2 \\
\hline 11 & Hamsath Palli & 2.22 & 1.57 & 636.1 & 47.9 & 11.3 & - & 0.8 & 23.7 & - & 24.5 \\
\hline 12 & Pandath Palli & 2.28 & 1.65 & 271.0 & 33.1 & 4.7 & - & 1.2 & 20.4 & - & 21.6 \\
\hline 13 & Asha Palli & 2.29 & 1.76 & 1084.1 & 46.1 & 99.2 & 37.9 & 1.8 & 5.6 & 6.3 & 13.7 \\
\hline 14 & Near Asfa Masjid & 3.17 & 2.63 & 36.7 & 68.9 & 15.4 & - & 4.7 & 6.7 & - & 11.4 \\
\hline 15 & Vahathu Palli & 2.97 & 2.25 & 533.4 & 41.1 & 122.6 & 9.2 & 1.8 & 6.4 & 6.2 & 14.4 \\
\hline 16 & Kunthathu Palli & 3.05 & 2.26 & 40.0 & 113.5 & 12.3 & - & 8.3 & 7.4 & - & 15.7 \\
\hline
\end{tabular}

Depth of nearby well: in $\mathrm{m}$, bgl; WL: Water level in $\mathrm{m}$, bgl; H: Depth of investigation in $\mathrm{m}$.

Table 3. Chemical parameters during pre- and post-monsoons.

\begin{tabular}{|c|c|c|c|c|c|c|c|}
\hline \multirow{2}{*}{$\begin{array}{l}\text { Sl. } \\
\text { no. }\end{array}$} & \multirow{2}{*}{$\begin{array}{l}\text { Chemical } \\
\text { parameters }\end{array}$} & \multicolumn{3}{|c|}{ Pre-monsoon } & \multicolumn{3}{|c|}{ Post-monsoon } \\
\hline & & Min. & Max. & Avg. & Min. & Max. & Avg. \\
\hline 1 & $\mathrm{pH}$ & 6.6 & 7.27 & 6.98 & 6.68 & 7.04 & 6.85 \\
\hline 2 & $\mathrm{EC}$ & 598 & 3550 & 1374.97 & 457 & 1515 & 871.51 \\
\hline 3 & TDS & 389 & 2308 & 893.73 & 274 & 909 & 522.59 \\
\hline 4 & $\mathrm{TH}$ & 250 & 751 & 424.94 & 228 & 692 & 432.00 \\
\hline 5 & $\mathrm{Ca}$ & 20 & 146 & 80.80 & 36.8 & 153.6 & 77.30 \\
\hline 6 & $\mathrm{Mg}$ & 6.1 & 170 & 54.21 & 11.52 & 127.7 & 58.95 \\
\hline 7 & $\mathrm{Na}$ & 16 & 452 & 117.97 & 22 & 82 & 51.37 \\
\hline 8 & $\mathrm{~K}$ & 0.1 & 25.9 & 5.85 & 1.0 & 4.0 & 2.12 \\
\hline 9 & $\mathrm{HCO}_{3}$ & 268 & 708 & 455.17 & 332 & 751.5 & 519.40 \\
\hline 10 & $\mathrm{Cl}$ & 28 & 865 & 175.66 & 39.7 & 348.8 & 138.21 \\
\hline 11 & $\mathrm{SO}_{4}$ & 14 & 96 & 46.51 & 18.2 & 51 & 29.96 \\
\hline 12 & $\mathrm{NO}_{3}$ & 0.05 & 122 & 15.69 & 0.33 & 20.6 & 3.50 \\
\hline
\end{tabular}

All contents are in $\mathrm{mg} / \mathrm{l}$ except $\mathrm{pH} ; \mathrm{EC}$ is in $\mu \mathrm{S} / \mathrm{cm}$ at $25^{\circ} \mathrm{C}$.

Min. = Minimum, Max. = Maximum, Avg. $=$ Average

\section{Conclusions}

Geophysical studies indicate that the fresh groundwater is available between 2.5 and $5.0 \mathrm{~m}$ depth; beyond that slowly signals of deterioration started appearing. At $10.0 \mathrm{~m}$ depth, true resistivity is varying from 5.0 to $100.0 \Omega \mathrm{m}$, the low resistivity being appeared at the eastern part of the island. Further, it is found that at $20.0 \mathrm{~m}$ depth nearly half of the island is showing resistivity of $5.0-15.0 \Omega \mathrm{m}$. So it is clear that there is seawater impact on the water bearing formation at a very shallow depth of $10.0 \mathrm{~m}$. The more influence is seen on the peripherals of eastern and western parts of the island.

Geochemical studies show that the EC $(>1500 \mu \mathrm{S} / \mathrm{cm})$ and content of $\mathrm{Cl}(>250 \mathrm{mg} / \mathrm{l})$, are more than the permissible limits in the peripheries of eastern and western parts of the island particularly during the pre-monsoon, and also to some extent during the post-monsoon seasons. This may be due to influence of saline water. 


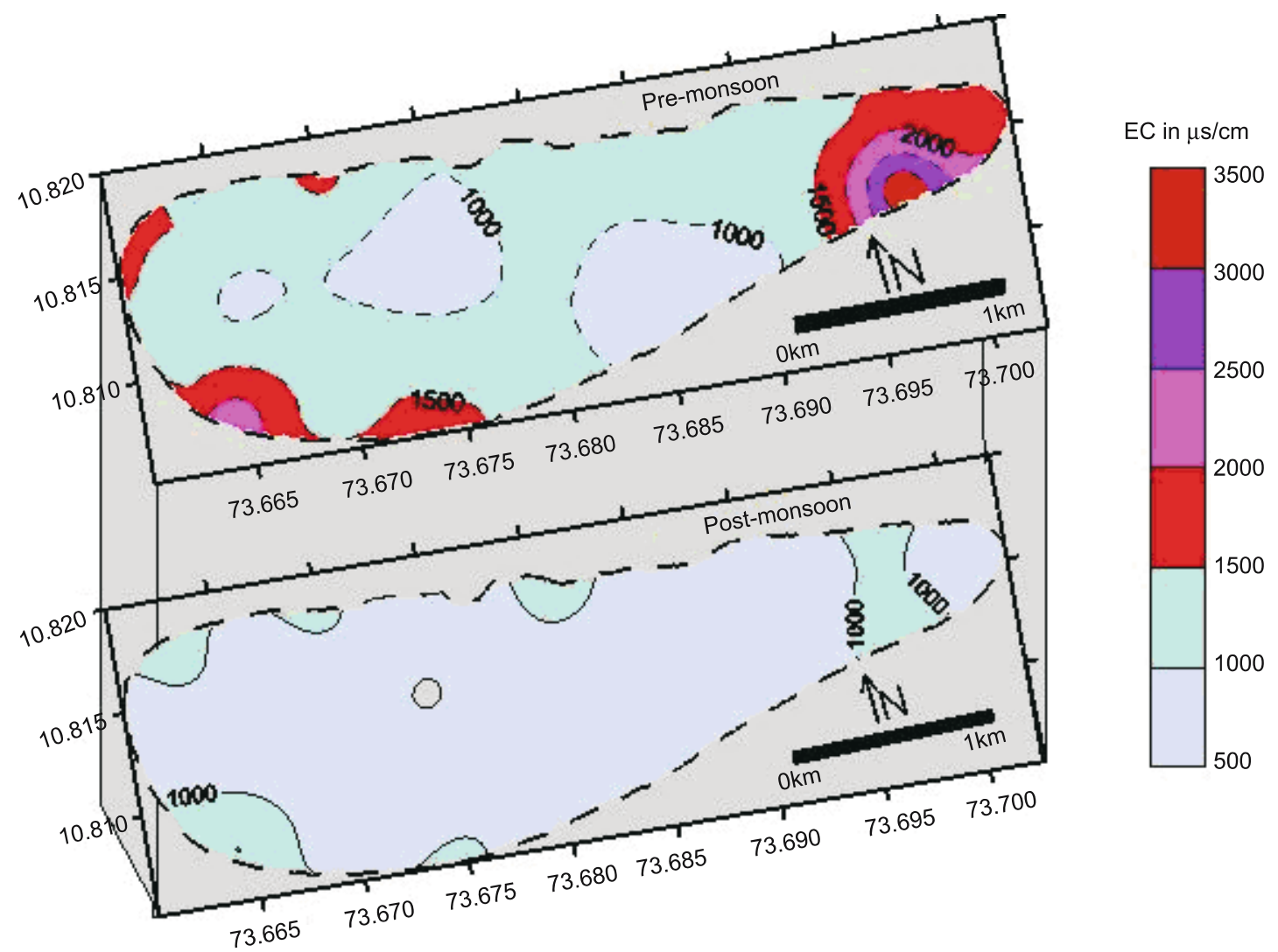

Figure 11. EC contouring pre- and post-monsoons.

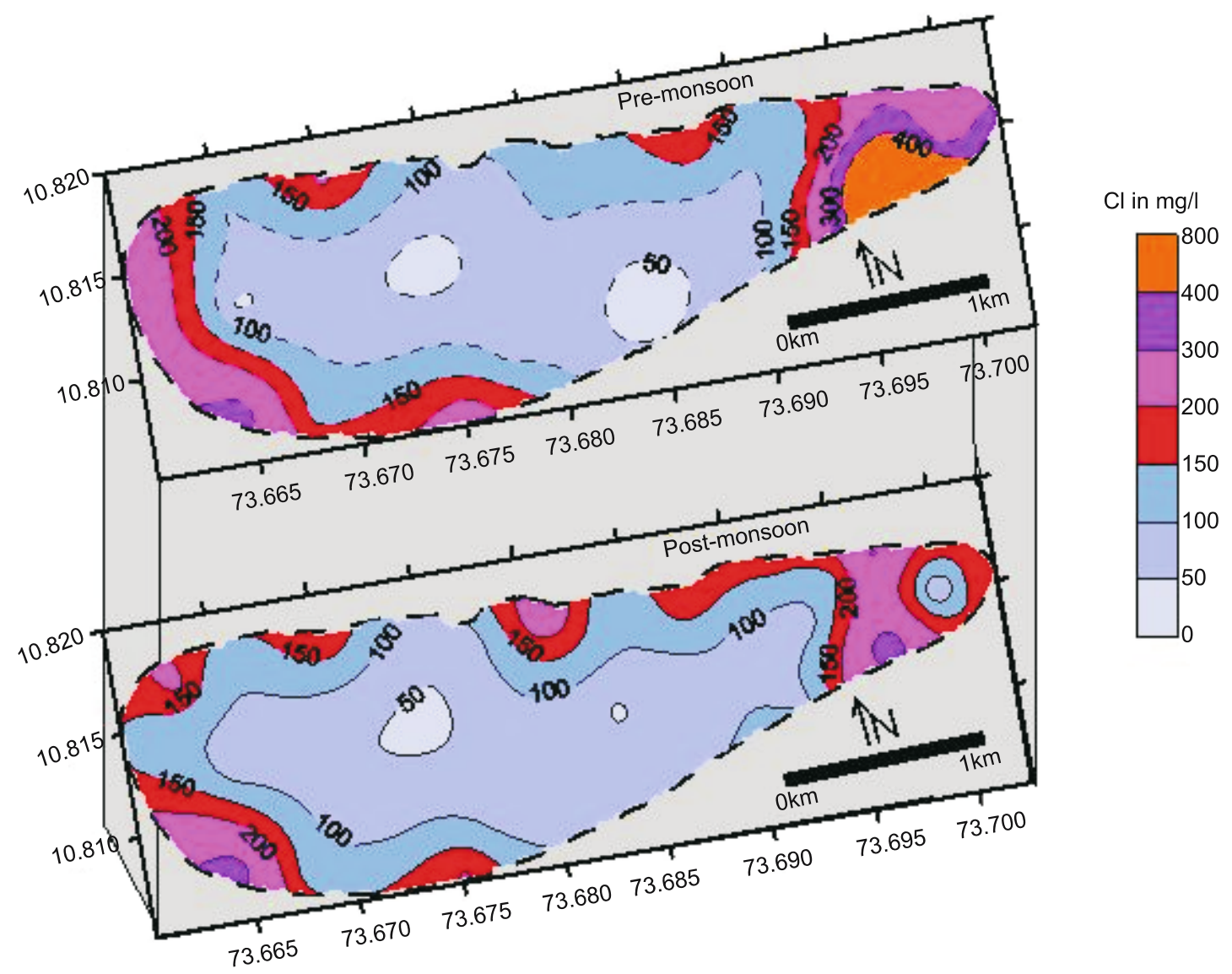

Figure 12. Chloride contouring pre- and post-monsoons. 
As the transmissivity is found to be higher of the order of $500-1200 \mathrm{~m}^{2} /$ day in the eastern part of the island, it increases the possibilities of seawater ingress. So, particularly the eastern part of the island is more vulnerable for seawater ingress.

These integrated studies of hydrogeological, geochemical and geophysical parameters indicate that the eastern parts as well as peripherals of western part of the island are more vulnerable for seawater ingress. So, immediate steps to be taken like usage of limited fresh groundwater resources, rainwater harvesting, etc., to stop the seawater ingress and its further encroachment/spread on the island.

\section{Acknowledgements}

The officials of PWD and DST-Lakshadweep have been helpful in carrying out various studies at Andrott Island. The entire study has been financed by DST, New Delhi. The authors thank Dr. V P Dimiri, Director of NGRI, Hyderabad for giving permission to publish this paper and the anonymous reviewers for providing valuable suggestions to improve the manuscript.

\section{References}

Ajaykumar V R and Ramachandran K K 1996 Resistivity survey for describing the fresh water lenses of Agatti atoll, Lakshadweep, India; J. Assoc. Expl. Geophys. 17(1) $11-16$.

Ajaykumar V R, Unnikrishnan K R and Ramachandran K K 1995 Groundwater resource potential in the union territory of Lakshadweep, India; Indian J. Earth Sci. 22(4) 165-170.

American Public Health Association (APHA) 1985 Standard methods for the examination of water \& waste; 16 th edn; Am. Public Health Assoc. Washington DC, 100 pp.

Banerjee P, Sarwade D V and Singh V S 2008 Characterization of an island aquifer from tidal response; Environ. Geol. 55 901-906.

Domenico P A and Schwartz F W 1990 Physical and chemical hydrogeology (New York: Wiley).

Gupta C P and Singh V S 1988 Flow regime associated with partially penetrating large diameter wells in hard rocks; J. Hydrol. 103 209-217.

Hem J D 1970 Study and interpretation of chemical characteristics of natural waters; 2nd edn. USGS Water Supply Paper, Washington DC 1473363 pp.
Indian Standard Institution (ISI) 1983 Indian Standard Specification for drinking water; New Delhi, Publ. No. IS-10500-1983.

Karanth K R 1987 Groundwater assessment, development and management (New Delhi: Tata McGraw-Hill Publ. Co. Ltd.) $720 \mathrm{pp}$.

Lloyd J W, Miles J C, Chessman G R and Bugg S F 1981 A groundwater resources study of a Pacific Ocean atollTarawa, Gilbert Islands; Water Resources Bull. 16(4) 646-653.

Mallik T K 2001 Some geological aspects of the Lakshadweep Atolls, Arabian Sea; J. Geol. Surv. India Spec. Publ. 56 1-8.

Mandel S and Shiftan Z L 1980 Groundwater resources investigation and development (New York: Academic Press).

Muralidharan M P and Pravan Kumar P 2001 Geology and geomorphology of Kavaratti Island, U.T. of Lakshadweep; J. Geol. Surv. India Spec. Publ. 56 9-13.

Nazeeb K M 1995 Groundwater resources and management in the Union Territory of Lakshadweep, Part II: Andrott and Minicoy Island; CGWB Report, Kerala Region, 43 pp.

Orellana E and Mooney H M 1966 Master tables and curves for vertical electrical sounding over layered structures; Interciencia, Madrid, Spain, p. 193.

Piper A M 1944 A graphic procedure in the geochemical interpretation of water analyses; Trans. Am. Geophys. Union 25(6) 914-928.

Prasada Rao G S L H V 1994 Water management in coconut; Proc. of the National seminar on Water Management for Plantation Crops, CWRDM, Kozhikode, pp. $65-70$.

Revichandran D, Vijayan P R, Sajeev R and Sankaranarayanan V N 2001 Monitoring beach stability and littoral processes at Androth and Kalpeni Islands, Lakshadweep; J. Geol. Surv. India Spec. Publ. 56 $221-227$.

Rushton K R and Redshaw S C 1979 Seepage and groundwater flow (New York: John Wiley) $339 \mathrm{pp}$.

Sarwade D V, Nandakumar M V, Kesari M P, Mondal N C, Singh V S and Bhoop Singh 2007 Evaluation of seawater ingress into an Indian Attoll; Environ. Geol. 52(2) $1475-1483$.

Singh V S 1999 Interpretation of pumping test data from large diameter wells on an oceanic island; Environ. Geol. 38(2) 168-170.

Trivedy R K and Goel P K 1984 Chemical and biological methods for water pollution studies; Environ Publ. Karad (India).

Vender Velpen B P A 1988 A computer processing package for D.C. Resistivity interpretation for IBM compatibles; ITC J. Vol. 4, The Netherlands.

Wagle B G and Kunte P D 1993 Photo-geomorphologic study of representative islands of Lakshadweep; Indian J. Marine Sci. 22(3) 203-209. 